\title{
Review on PRNP genetics and susceptibility to chronic wasting disease of Cervidae
}

\author{
Katayoun Moazami-Goudarzi ${ }^{*} \mathbb{D}$, Olivier Andréoletti ${ }^{2}$, Jean-Luc Vilotte ${ }^{1}$ and Vincent Béringue ${ }^{3}$
}

\begin{abstract}
To date, chronic wasting disease (CWD) is the most infectious form of prion disease affecting several captive, free ranging and wild cervid species. Responsible for marked population declines in North America, its geographical spread is now becoming a major concern in Europe. Polymorphisms in the prion protein gene (PRNP) are an important factor influencing the susceptibility to prions and their rate of propagation. All reported cervid PRNP genotypes are affected by CWD. However, in each species, some polymorphisms are associated with lower attack rates and slower progression of the disease. This has potential consequences in terms of genetic selection, CWD diffusion and strain evolution. CWD also presents a zoonotic risk due to prions capacity to cross species barriers. This review summarizes our current understanding of CWD control, focusing on PRNP genetic, strain diversity and capacity to infect other animal species, including humans.
\end{abstract}

Keywords: CWD, Cervidae, prions, polymorphisms, strains, zoonosis, transgenic mice, host pathogen interaction

\section{Table of Contents}

1 Introduction

2 CWD epidemic in North America

3 CWD emergence in Scandinavia

4 No etiological link between North American and Scandinavian CWD strains, potential consequences

5 Interspecies transmission of CWD

6 Can PRNP polymorphism help controlling CWD propagation?

6.1 Subfamily Capreolinae

6.1.1 Odocoileus virginianus or white-tailed deer (WTD)

6.1.2 Odocoileus hemionus or mule deer

6.2 Rangifer tarandus (Eurasian wild tundra reindeer, caribou)

*Correspondence: Katayoun.goudarzi@inrae.fr

${ }^{1}$ University Paris-Saclay, INRAE, AgroParisTech, GABI, 78350 Jouy-en-Josas, France

Full list of author information is available at the end of the article
6.2.1 Capreolus capreolus or roe deer

6.2.2 Alces alces or moose

6.3 Subfamily Cervinae

6.3.1 Cervus elaphus canadensis (wapiti) and Cervus elaphus nelsoni (rocky mountain elk)

6.3.2 Cervus elaphus elaphus or European red deer

6.3.3 Cervus nippon or sika deer

6.3.4 Dama dama dama or fallow deer

7 Conclusion

References

\section{Introduction}

Mammalian prions are responsible for six transmissible spongiform encephalopathies (TSEs) in Human; sporadic and familial Creutzfeldt Jakob disease (CJD), variant CJD, Kuru disease, Gerstmann-Straüssler-Scheinker syndrome, fatal familial insomnia and variably proteasesensitive prionopathy. These progressive neurological degenerations are invariably fatal. A key feature in TSE pathogenesis is the accumulation of the host-encoded original author(s) and the source, provide a link to the Creative Commons licence, and indicate if changes were made. The images or other third party material in this article are included in the article's Creative Commons licence, unless indicated otherwise in a credit line to the material. If material is not included in the article's Creative Commons licence and your intended use is not permitted by statutory regulation or exceeds the permitted use, you will need to obtain permission directly from the copyright holder. To view a copy of this licence, visit http://creativecommons.org/licenses/by/4.0/. The Creative Commons Public Domain Dedication waiver (http://creativeco mmons.org/publicdomain/zero/1.0/) applies to the data made available in this article, unless otherwise stated in a credit line to the data. 
cellular prion protein $\left(\mathrm{PrP}^{\mathrm{C}}\right)$ into a misfolded aggregated conformer $\operatorname{PrP}^{\mathrm{Sc}}$ that is the principal, if not the sole, constituent of the infectious agent (called prion). TSEs also exist in a wide range of animals, including bovine spongiform encephalopathy (BSE) in cattle, scrapie in sheep and goats, transmissible mink encephalopathy, feline spongiform encephalopathy, camel prion disease, exotic ungulate spongiform encephalopathy and chronic wasting disease (CWD). CWD affects captive, free ranging (semidomesticated) and wild Cervidae.

Following an incubation period of 2-4 years in wild Cervidae, CWD-affected animals develop behaviour, sensory and locomotor signs that are pathognomonic of TSEs [1]. Clinical signs include isolation from the herd, listlessness, lowering of head and ears, hyper-excitability, progressive weight loss but also polydipsia, polyuria, ruminal atony, drooling, teeth grinding, and loss of fear of human. At the late stage of the disease, clinical signs include respiratory distress, emaciation, ataxia, depression and weakness. To date, CWD is probably the most infectious TSEs [2]. CWD transmission occurs mostly horizontally by animal contact and the environment due to prion excretion from infected animals. CWD is characterized by an extensive deposition of $\operatorname{PrP}^{\mathrm{Sc}}$ (termed here $\operatorname{Pr} P^{C W D}$ ) and of infectivity in the CNS and in the lymphoid tissue. In addition $\operatorname{PrP} \mathrm{P}^{\mathrm{CWD}}$ and infectivity can be discarded in bodily fluids (urine, faeces, saliva), placenta, decomposing carcasses from dead animals and fomites from the suites of infectious deer prions [3-5]. Edible tissues in which $\operatorname{PrP}^{\mathrm{CWD}}$ has been detected are heart, liver, kidney, tongue, pancreas, blood, adipose tissue, lymphoreticular system and antler velvet [6-11]. An increasing phenomenon of antler cannibalism was recently quantified among the affected reindeer population from Norway and found to potentially contribute to CWD emergence [12]. CWD prions bound to soil components where TSE-infected animals stood, persist for many years (at least 16 years for scrapie sheep [13]) and remain infectious by the oral route of exposure [14]. Variations in soil types and mineralogy, clay and humus content are the main factors responsible for $\operatorname{PrP}^{\mathrm{Sc}}$ persistence and recovery after prolonged incubation $[15,16]$. While, an organic soil component, humic acids, can decrease CWD infectivity [17], soils from meadow regions (montmorillonite, mineralogy and high humus content) show high ability to bind $\mathrm{PrP}^{\mathrm{CWD}}$ and increased infectivity. A time-dependent decline in recovery of $\operatorname{PrP}^{\mathrm{CWD}}$ has been found but does not correlate with prion infectivity levels [18]. In addition, after serial protein misfolding cyclic amplification, $\operatorname{Pr} \mathrm{P}^{C W D}$ is detected in environmental water and mineral licks $[19,20]$. Thus, human activities, like supplemental feedings, can increase the rate of aggregation and the likelihood of disease transmission. A recent study estimated that the contact rates in Elk population from Wyoming were 2.6 times larger when feeding occurred [21].

\section{CWD epidemic in North America}

CWD has spread into populations of wild Cervidae. Its geographic range and prevalence are constantly increasing in North America (up to $4 \%$ per year). The USA has, so far, the most widespread CWD infection worldwide, due to its presence for at least 50 years. CWD frequently occurs in domestic animals followed by cases in the wild population thanks to breeding conditions and husbandry systems that allow direct or indirect contact between farm animals and wildlife populations. Furthermore, CWD transmission is more effective in highdensity herds and the disease prevalence may be more a function of social and foraging behaviour differences between species. This prevalence typically declines with distance from heavily affected areas and the landscape connectivity plays a major role in the spread of the disease [22]. CWD was first observed in a mule deer (Odocoileus hemionus) in a Colorado research facility in 1967. It was discovered in 1981 in wild deer [23, 24]. In Canada, CWD was reported in 1977 at the Toronto Zoo, after importation of CWD-infected animals from a US zoo. A 2006 study by Dubé et al. retrospectively investigated the occurrence of CWD in 105 animals that died at the Toronto Zoo from 1973 to 2003 [25]. CWD was detected in 7 mule deer (died between 77 and 79) and 1 blacktailed deer (died in 1981). In 2000, CWD was detected in a wild mule deer in Saskatchewan, Canada [26]. To date, the disease is present in 26 states of the USA and three Canadian provinces (United States Geological survey, National Wildlife Health Center, updated May 2021). CWD prevalence could reach $79 \%$ in captive herds, e.g. White-Tailed Deer (WTD) from south-central Wisconsin [27] and 33\% in wild populations, e.g. high-prevalence CWD endemic area like Wyoming. In this hunting area, an intense monitoring study, conducted from 2003 to 2010 via radio-telemetry and global positioning system collars, determined that CWD was the cause of a $10.4 \%$ annual decline in free ranging WTD population [28]. In south-eastern Wyoming, average annual CWD prevalence in mule deer exceeds $20 \%$ and contributes to a $21 \%$ annual population decline [29].

In 2001, epidemiological investigations confirmed that CWD was introduced to the Korean peninsula by captive elk (Cervus elaphus nelsoni), imported from Canada in 1994 and 1997 [30, 31]. CWD was subsequently detected in farmed elk populations in 2001, 2004, 2005, 2010 and 2016 and since no evidence of natural CWD transmission to sika deer has been documented [32]. In other countries, CWD was not reported until 2016. 


\section{CWD emergence in Scandinavia}

In 2016, following routine surveillance, four CWD cases were documented in wild Eurasian tundra reindeer (Rangifer tarandus tarandus) located in the zone 1 of Nordfjella mountain, in southern Norway [33, 34]. Following these cases, an unprecedented CWD eradication campaign was performed between 2016 and 2018. Hunting $(N=582)$, professional marksmen interventions $(N=1399)$ or normal animal deaths $(N=43)$ resulted in the eradication of this entire subpopulation [35]. Analysis of the dead animals for the presence of CWD prions resulted in a $1.6 \%$ prevalence in this adult population [36].

The Norwegian wild Eurasian tundra reindeer population is fragmented in 23 separated sub-populations. The above-mentioned eradicated subpopulation constituted approximately $10 \%$ of the wild European tundra reindeer population. On September 2020, one more reindeer positive case was identified in a separated population located in Hardangervidda. This region is considered to account for the largest wild Norwegian Eurasian tundra reindeer subpopulation with about $10-11000$ reindeer. To date 14 males and 6 females, aged between 1.5 to 8 years, have been tested positive for CWD in reindeer from Norway. In 2017, one Norwegian red deer (Cervus elaphus elaphus) was identified from the 4082 tested. This 16-yearold female was shot by a hunter in October 2017 in the Gjemnes municipality in western Norway and had no signs of disease.

The third CWD positive species identified so far in Scandinavia is the moose (Alces alces). Seven cases, aged between 10 to 20 years, were identified in Eastern Norway. These cases were located in Selbu $(N=3)$, Lierne $(N=1)$, Sigdal $(N=1)$, Flesberg $(N=1)$ and Steinkjer $(N=1)$ municipalities $[37,38]$. Based on seasonal migrations, it is considered that they likely represent different moose subpopulations [39, 40]. In Easter Finland, one found dead 15-year-old case was reported in 2018. A second elderly case was found in November 2020 in an 18-year-old moose put down due to sickness (Finnish Food Authority). Lastly, 3 cases were identified in female moose (10, 16, 16 years old) in 2019 in Northern Sweden. While the two old females were observed emaciated or showing behavioural changes in the municipality of Arjeplog and Arvidsjaur, the youngest female was shot in the municipality of Arjeplog during the hunting season without signs of illness [41]. A fourth case was reported in September 2020 (14-year-old female) in the county of Västerbotten. This moose was euthanised after being observed walking on three legs only.

Thus, to date in Europe, 34 free ranging CWD cases have been documented in Norway $(N=28)$, Northern Sweden $(N=4)$ and Eastern Finland $(N=2)$. Whereas in reindeer, $\operatorname{PrP}^{C W D}$ was detected in the brain and in certain lymphoid organs, an indication of contagiousness, in moose and red deer, $\operatorname{PrP} \mathrm{PWD}^{\mathrm{CW}}$ was only detected in the CNS. New types of CWD with atypical characteristics were thus considered [33, 35, 39, 41-43].

\section{No etiological link between North American and Scandinavian CWD strains, potential consequences}

As for conventional pathogens, different strains of prions can be identified in the same host species. Prion strains exhibit specific biological traits including time to disease onset, neuropathological patterns of vacuolation and $\mathrm{PrP}^{\mathrm{Sc}}$ deposition in the brain, and capacity to replicate in the lymphoid tissue. A large body of evidence indicates that prion strain information is encoded within $\mathrm{PrP}^{\mathrm{Sc}}$ conformation (reviewed in [44]).

A large set of physio-pathological and biochemical criteria can be used to distinguish between prion strains [45]. Among them is the serial transmission to laboratory rodents such as mouse and hamster and the characterization of the disease phenotype. Because of the species barrier that can limit prion transmission from one species to another, prions from naturally infected species may not transmit to laboratory rodents, even at high dose and by intracerebral inoculation. In particular, CWD prions poorly transmit to conventional mice [46]. In this respect, transgenic modelling of animal and human prion diseases by engineering mice to express $\mathrm{PrP}^{\mathrm{C}}$ from the species of interest has proved incredibly useful for strain typing studies as these models usually lack a transmission barrier against prions from the same species. CWD prions do not escape this rule and propagate in transgenic mouse models expressing cervid PrP. However, so far, the number of CWD strain typing studies has remained relatively rare compared to the number of cases identified and the diversity of species affected, limiting de facto our understanding of the number of strains circulating in a given species and of their capacity to adapt to others.

In a seminal study led by Angers et al. [47], two phenotypically different strains named CWD1 and CWD2 were identified by transmission of a panel of CWD-positive isolates from elk (11 cases), mule deer (16 cases) or WTD (1 case) to cervid PrP mice overexpressing deer $\operatorname{PrP}^{\mathrm{C}}$ (with $Q$ at codon 226). In deer, these two strains were frequently found to co-propagate. Co-propagation of distinct prion strains is not unusual in TSEs, as shown with human prion strains in CJD affected individuals [48] and with classical scrapie strains in sheep and goats [49].

Non-transgenic laboratory animals can be fairly susceptible to prions from different species, as exemplified by bank voles in which sporadic forms of CJD could be propagated without a transmission barrier [50]. Such 
studies were instrumental to demonstrate that the force of the species barrier is more a question of conformational compatibility between $\operatorname{PrP}^{\mathrm{C}}$ and the prion strain type than a species identity $[45,51]$. Bank voles (expressing I at codon 109) were also shown to be highly susceptible to CWD prions [52]. Recently, the strain properties of a panel of Canadian CWD isolates (elk, WTD and moose) were compared with those from Norway (reindeer and moose) upon transmission to bank voles. No commonalities between the Canadian and Norwegian isolates were found, in terms of disease tempo on serial passage in bank voles, neuropathology and biochemical properties of $\operatorname{PrP}^{\mathrm{Sc}}$ that accumulated in the brains of the infected animals. For example, the incubation time to disease at $3^{\text {rd }}$ passage (i.e. when prions are considered adapted to their hosts during cross-species transmission) was very short after inoculation with Canadian CWD prions (35 days) and significantly prolonged and variable after inoculation with Scandinavian isolates (76 (Moose), 105 (Reindeer) and 175 days (Moose)). Further, three different strains were isolated on transmission of CWD-positive Norwegian moose (2) and reindeer (1) [53]. This strain diversity and the absence of etiological link with North American CWD prions was unexpected.
In the natural host, polymorphisms at position 95 and 96 from WTD $\operatorname{PrP}^{C}$ were shown to impact CWD strain diversification, either by generating new strains or selecting specific conformers [54]. Another polymorphism in this sequence at codon 116 was found to affect prion strain properties, allowing emergence of new strain types [55]. Thus, PRNP polymorphisms in Cervidae are likely contributors to prion strain diversity and evolution but their impact on the observed differences between North American and Scandinavian isolates remains to be substantiated.

Worryingly, these transmission studies mean that the precise origin of CWD in Europe remains enigmatic and what has been learned from the North American epidemic cannot be readily extrapolated to the European outbreak. Environmental contamination, contagiousness, risks of interspecies transmission and zoonotic potential of European CWD should thus need to be thoroughly assessed.

\section{Interspecies transmission of CWD}

The Cervidae family includes 40 species of deer that are widely divergent in size, habitat and behaviour. This family is divided into Capreolinae and Cervinae subfamilies [56].

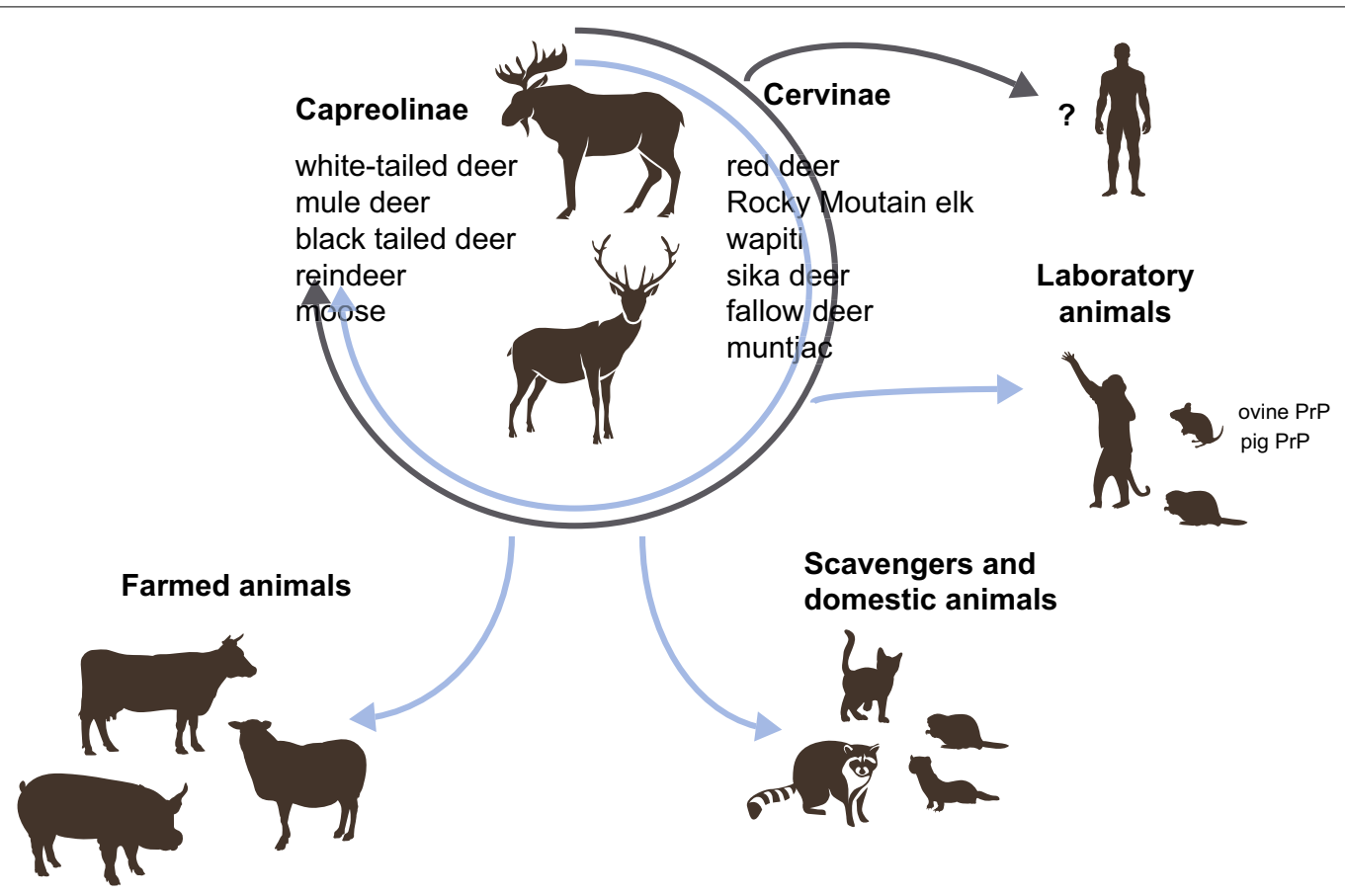

Figure 1 The host range of CWD prions. CWD prions circulate in the Cervidae reservoir (free-ranging and captive or semi-captive animals). While CWD prion strain diversity extend in the Cervidae reservoir is unknown, the strains identified so far in the North-American and European reservoirs are different. North-American CWD prions are able to propagate naturally (grey arrow) or experimentally (blue arrows) in many different species. The impact of intermediate hosts replication on the evolution and zoonotic potential of CWD prions is unknown. Many laboratory species have been experimentally infected with CWD prions, including hamsters, bank voles, transgenic mice expressing ovine or pig PrP and squirrel monkeys. CWD zoonotic threats to humans remain unclear. 
After natural or experimental infection by oral or intracerebral routes, CWD prions from North America were found to propagate in several members of both subfamilies [22]. Those include WTD (Odocoileus virginianus), mule deer (Odocoileus hemionus), black tailed deer (Odocoileus hemionus columbianus), reindeer (Rangifer tarandus) and moose (Alces alces) in Capreolinae (Figure 1). In Cervinae, red deer (Cervus elaphus elaphus), Rocky Mountain elk (Cervus elaphus nelsoni), wapiti (Cervus elaphus canadensis), sika deer (Cervus nippon), fallow deer (Dama dama) and muntjac (Muntiacus reevesi) can be CWD-positive [57, 58].

North American CWD can be experimentally transmitted by intracerebral route to farmed animal species such as pig [59], sheep [60, 61] and cattle [62-66]. By oral route of inoculation, CWD prions are detected in the lymphoid tissue from pig six months after inoculation [59]. Transmission to transgenic mice expressing ovine, and porcine PrP also suggested that CWD prions can propagate in these farm species $[67,68]$. In ovinized mice, replication was restricted to the lymphoid tissue, probably because the transmission barrier is lower in this tissue [67]. Furthermore, CWD can be experimentally transmitted to other non-cervid species such as several species of voles [52, 69], white-footed mice [30], Syrian golden hamsters [70], ferrets [71], raccoons [72] and cats [73]. The within- and inter-species transmission potential of CWD is thus relatively large (Figure 1).

So far, no epidemiological evidence supports CWD transmission to human [74]. Non-human primates and transgenic mice expressing human PrP are the most relevant models to address prion zoonotic potential in vivo. Intracerebral and oral inoculation of squirrel monkey with North American CWD induced a typical TSE [11, 75]. Contradictory results have been obtained in macaques, which are considered phylogenetically closer to humans [76, 77]. Humanized transgenic mice did not develop disease after intracerebral inoculation of North American CWD prions [78, 79].

Due to their recent identification, many studies are still ongoing and needed to assess the zoonotic risks associated with the Scandinavian CWD strains and help determining strategies to limit their impact on the wild and farm-populations. Recently, it was shown that humanized mice resisted infection with these agents (primary passage negative) [80]. A larger set of experiments, including

(i) transgenic models in which peripheral replication can be addressed because prion zoonosis can be tissue specific [67],

(ii) a larger panel of CWD isolates from different species because it can impact the transmission properties as exemplified with sheep-passaged BSE [81], are necessary to conclude on the zoonotic potential of CWD prions.
Besides, some studies focusing on molecular evolution, variability of the prion gene and their effect on the structure of the protein, predicted potential interspecies transmission of CWD. For example, Pronghorn antelopes were predicted to be susceptible to CWD, while bighorn sheep, mountain goats and bison would be more resistant [82]. Experimental demonstration of these predictions remains to be performed. Collectively, these findings highlight that CWD, due to its high proportion to horizontal transfer, to contaminate the ecosystem and to its yet incompletely known zoonotic properties, is a highly problematic ecological, economical, agricultural disease with potential threats to human health.

\section{Can PRNP polymorphism help controlling CWD propagation?}

Naturally occurring, polymorphisms of the prion protein encoding gene $(P R N P)$, an evolutionary well conserved gene in mammalian species, have a direct impact on the susceptibility or resistance to prions. Studies in sheep scrapie have been instrumental in demonstrating the importance of PRNP genetics in the etiopathogenesis of the disease. In sheep, a range of susceptibility to classical scrapie has been established mainly based on variations at codons A136V, R154H and Q171R, with $\mathrm{V}_{136} \mathrm{R}_{154} \mathrm{Q}_{171}$ considered the most susceptible haplotype and homozygous $A_{136} R_{154} R_{171}$ the most resistant. This finding has been used worldwide by many breeding policies to eradicate scrapie [83-85]. In goats, mutations at codons 142 (I/M), 143 (H/R), $146(\mathrm{~N} / \mathrm{S}), 154(\mathrm{R} / \mathrm{H}), 211(\mathrm{R} / \mathrm{Q})$ and $222(\mathrm{Q} / \mathrm{K})$ were found to protect against natural scrapie [86-89]. In cattle, indel polymorphisms at the promoter region and intron 1 of PRNP were related to an increased BSE incidence [90]. In humans, the M129V PRNP polymorphism is strongly associated with variant and sporadic CJD. MV heterozygosity provides relative protection against acquired, sporadic, and some inherited prion diseases. Almost all clinical cases of variant CJD are found in M129 homozygous individuals. Another polymorphism, the G127V provides strong dominant protection against the Kuru disease and diverse prion isolates, as examined by transgenic modelling [91, 92]. In this chapter, we summarize the current knowledge on the potential genetic control of CWD propagation in different cervid populations with an illustration of aa variations within the open reading frame (ORF) of cervid PRNP (Figure 2). 


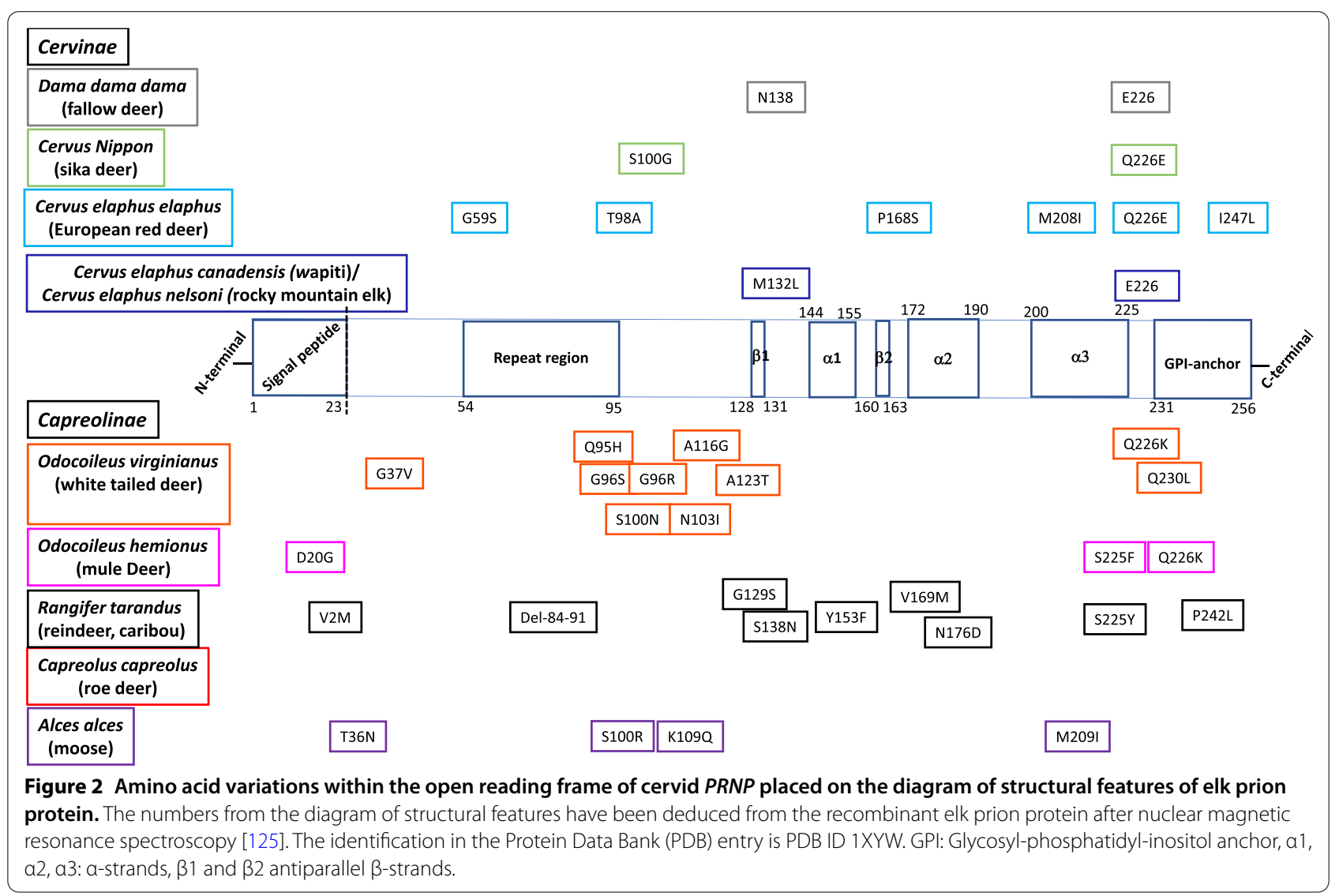

\subsection{Subfamily Capreolinae}

\subsubsection{Odocoileus virginianus or white-tailed deer (WTD)}

To date, nucleotides variants were observed in WTD at 23 positions; 14 synonymous substitutions at aa positions $20,51,81,95,108,124,126,139,146,147,156$, 166, 185, 202 and 10 non-synonymous substitutions at aa positions G37V, Q95H, G96S or G96R, S100N, N103I, A116G, A123T, Q226K, Q230L encoding 13 different PrP variants. $40 P R N P$ haplotypes were reported (designated A through Z, PRNP-Odvi27 to PRNP-Odvi38 and AR1, AR2) [93-97].

Very recently, studies with dense sampling allowing formal statistical analysis even on rare PRNP alleles were published. One of these studies analysed 9434 farmed WTD from 144 herds in Canada and USA. Among them, 7343 animals were from healthy herds and 2091 from depopulated herds following exposure to CWD with a prevalence rate of $34.1 \%$ [93]. Four critical codons were identified at position 95, 96, 116 and 226. At the time of depopulation, 96GG animals were associated with the higher percentage of CWD and the most severe disease stages. 96G/116G, 96GS or 96G/226K and 95H96G had an intermediate position, although for the $96 \mathrm{G} / 226 \mathrm{~K}$ genotype these differences were not statistically significant.
96SS had the most reduced risk of being CWD-positive and, if positive, were at a significantly earlier stage of disease progression. Still, CWD occurred in $17.5 \%$ of $96 \mathrm{SS}$ animals. This suggested that $95 \mathrm{HH}$ and to a lesser extend 116GG or 226KK homozygotes may have a lowest odds ratios for being found CWD positive with an additive mixed effects model developed to predict outcomes for genotypes with insufficient data [93].

A genetic screening of 2899 free-ranging WTD sampled between 2002 and 2017 from Illinois and Southern Wisconsin with a low CWD prevalence rate of $1 \%$ to $2 \%$ identified 38 haplotypes [94]. Out of 2754 tested WTD, 407 were CWD-positive and 2347 were CWDnegative. They corresponded to 34 haplotypes and 11 different PrP variants. Seven haplotypes were present at $a>0.01 \%$ frequency while the others were rare. These haplotypes correspond to three PrP variants termed: A $\left(\mathrm{Q}_{95} \mathrm{G}_{96} \mathrm{~S}_{100} \mathrm{~N}_{103} \mathrm{~A}_{123} \mathrm{Q}_{226}\right), \quad \mathrm{C} \quad\left(\mathrm{Q}_{95} \mathrm{~S}_{96} \mathrm{~S}_{100} \mathrm{~N}_{103} \mathrm{~A}_{123} \mathrm{Q}_{226}\right)$ and $\mathrm{F}\left(\mathrm{H}_{95} \mathrm{G}_{96} \mathrm{~S}_{100} \mathrm{~N}_{103} \mathrm{~A}_{123} \mathrm{Q}_{226}\right)$, which were detected at a $0.74,0.17$ and 0.05 frequency, respectively. $\mathrm{C}$ and $\mathrm{F} \operatorname{PrP}$ variants were associated with significantly lowered CWD susceptibility compared to A PrP variant, with AA animals showing the highest susceptibility to CWD. F PrP variant had a greater impact than $C \operatorname{PrP}$ 
variant in lowering CWD susceptibility; 3\% of CC deer were CWD-positive while no FF or CF deer were identified amongst CWD-positive animals. Variant $F$ effects on prion susceptibility resemble those described for sheep expressing the resistant allele $A_{136} R_{154} R_{171}$ [98]. A and $\mathrm{C} \mathrm{PrP}$ variants were similarly identified as the most common PRNP haplotypes in 1433 harvested WTD distributed across Arkansas, where CWD prevalence was estimated at $23 \%$ in 2015 [95]. They accounted for $82 \%$ and $16.71 \%$, respectively. Variant F was absent. Accordingly, A PrP variant was the most frequent within CWDpositive cases. Interestingly, the relative frequency of variant $C$ was over represented in older CWD-positive deer suggesting that this haplotype could slow the disease progression or reduce the likelihood of contracting the disease. Landscape constraints could contribute to a spatial heterogeneity of PRNP polymorphisms and impact the prevalence of reduced susceptibility genotypes [95]. Landscape features were also found in 728 free ranging WTD from Mid-Atlantic region, an area with recent history of infection and with low disease incidence [96]. The frequency of susceptible genotypes varied among subregions and even among counties within sub-regions separated by large geographical escarpments, large rivers, and/or high-volume traffic roads that influence genetic connectivity. In another study involving 7427 harvested WTD, an inverse relationship between forest habitat and odds of CWD infection was observed in the central Appalachian region of the north-eastern United States where the prevalence rate is $0.93 \%$ [99]. It is worth mentioning that the distance of deer dispersal is influenced by the amounts of forest cover, which could affect crosscontamination [100].

Overall, the protective influence of $95 \mathrm{H}, 96 \mathrm{~S}, 116 \mathrm{G}$ and $226 \mathrm{~K}$ alleles was pointed by different studies. These naturally occurring PrP polymorphisms produced concordant effect with orally inoculated deer [98, 101], transgenic mice expressing deer $\operatorname{PrP}[35,47,102]$ or during in vitro conversion [103]. Even if deer with protective variants may still be infected with CWD prions, increasing frequency of $\operatorname{PrP}$ haplotypes with variants $\mathrm{C}$ or $\mathrm{F}$ and reducing frequency of variant A may help controlling CWD in WTD [94]. However, the characterization of the infecting strain(s) in these natural conditions was not always assessed. This information is necessary for identifying spill over hosts and estimating the zoonotic potential [53]. Such breeding selection might also contribute to the emergence of new CWD strains [98].

\subsubsection{Odocoileus hemionus or mule deer}

To date, nucleotide variants were observed in mule deer at 5 positions; 2 synonymous substitutions at aa positions 131, 247 and 3 non-synonymous substitutions at aa positions D20G, S225F, Q226K [97, 104, 105]. Of note, only two heterozygous animals at codon 226 were identified in Nebraska mule deer $(N=122)$, suggesting a low percentage of animals carrying the $226 \mathrm{~K}$ allele.

Under experimental conditions mimicking typical exposure conditions, the $225 \mathrm{~F}$ allele provided a barrier to infection. After oral inoculation, accumulation and distribution of $\operatorname{PrP}^{\mathrm{CWD}}$ were similar between 225SF and 225SS deer, but the disease tempo differed. 225SF animals had an extended time to onset of clinical signs compared to their 225SS counterparts [9]. These results are concordant with those obtained when 225SS and 225FF mule deer are cohoused in a contaminated $0.5-\mathrm{Ha}$ paddock [106].

A survey on 1482 free ranging mule deer from Wyoming and Colorado with respect to PRNP polymorphisms at codon 225 revealed that animals with 225SS were 30 times more likely to be CWD-positive compared to their 225SF counterparts. No relationship between prevalence rates and genotype frequencies was identified [104]. The protective effect of allele $225 \mathrm{~F}$ was not observed in Nebraska based on twelve 225SF animals [105]. In another study on 289 unrelated deer from South Saskatchewan (Western Canada), homozygous 20D animals were less likely to be CWD-positive compared to 20GG or 20DG animals [97]. However, there is no definitive correlation between CWD status and PrP polymorphism at codon 20. Indeed, in Nebraska, the 20G allele was significantly associated with reduced odds of being CWD-positive [105] while, in Wyoming and Colorado $(N=363)$ this polymorphism was found to be independent of CWD status [104]. It remains to be evaluated if the same strain was present in all studied animals as different circulating strains may explain these seemingly different results.

Collectively, allele $225 \mathrm{~F}$ confers a protective effect in mule deer. At the molecular level, this allele has been proposed to induce structural rearrangements in the PrP globular domain, affecting the interaction between $\alpha 3$ helix and the $\beta 2-\alpha 2$ loop, and resulting in an increased stability that could interfere with $\operatorname{PrP}^{\mathrm{C}}$ to $\mathrm{PrP}^{\mathrm{Sc}}$ conversion rate [47].

\subsection{Rangifer tarandus (Eurasian wild tundra reindeer, caribou)}

To date, nucleotide variants at 9 positions and a $24 \mathrm{bp}$ deletion in the octapeptide repeat region (aa- 84-91) were observed in Rangifer species, leading to two synonymous substitutions at aa positions 2 and 146 and to 8 non-synonymous substitutions V2M, G129S, S138N, Y153F, V169M, N176D, S225Y and P242L [34, 107-110].

PRNP polymorphisms were studied in the Eurasian wild tundra reindeer (Rangifer tarandus tarandus) and 
in 3 North American caribou subspecies i.e. Alaskan caribou (Rangifer tarandus granti), Barren-ground caribou (Rangifer tarandus groenlandicus) and woodland caribou (Rangifer tarandus caribou), itself subdivided in two major ecotypes, boreal and mountain populations. Due to climate change and industrial development, many Canadian caribou populations are listed as either threatened or endangered. While caribou in Canada are reported free from CWD, some boreal caribou populations have an overlapping habitat with CWD-infected WTD.

Recently, a large scale PRNP genotyping was reported from 756 North American caribou sampled in 8 Barrengrounds, 6 mountain woodlands and 7 boreal woodlands caribou herds from two provinces and three western Canadian territories [107]. The analysis focused on the most frequent aa substitutions at positions 129, 138, 146, and/or 169. Rare substitutions at positions 153, 176, 242 and 2 (co-translationally cleaved off) were not considered. Among their pairwise comparisons, only polymorphism at position 138 was significantly different, with the presence of the $138 \mathrm{~N}$ allele at higher frequency in northern migratory barren ground caribou populations (36.8\%) compared to woodland caribous $(27.9 \%$ and $22.7 \%$ in mountain ecotype), when one boreal woodland caribou herd from Chinchaga (63.7\%) was excluded. For this latter, landscape features probably explain this high frequency because this herd is located in a habitat surrounded by higher elevation ground that contributes to its geographical isolation. The result from this study is concordant with previous ones conducted at a smaller scale $[108,109]$.

In central Southern Norway, a genetic screening was performed in 120 Eurasian wild reindeer (Rangifer tarandus tarandus). There was 101 healthy animals and 19 CWD-positive cases from Nordfjella zone 1 . This resulted in the identification of $5 \operatorname{PrP}$ variants, designated as $\mathrm{A}$ (ref sequence: $\left.\mathrm{V}_{2} \mathrm{G}_{129} \mathrm{~S}_{138} \mathrm{~V}_{169} \mathrm{~N}_{176} \mathrm{~S}_{225}\right)$, B $\quad\left(\mathrm{V}_{2} \mathrm{G}_{129} \mathrm{~S}_{138} \mathrm{~V}_{169} \mathrm{~N}_{176} \mathrm{Y}_{225}\right)$, $\mathrm{C} \quad\left(\mathrm{V}_{2}\right.$ del-84-91G $\left.\mathrm{G}_{129} \mathrm{~S}_{138} \mathrm{~V}_{169} \mathrm{~N}_{176} \mathrm{~S}_{225}\right)$, D $\left(\mathrm{V}_{2} \mathrm{G}_{129} \mathrm{~S}_{138} \mathrm{~V}_{169} \mathrm{D}_{176} \mathrm{~S}_{225}\right)$ and $\mathrm{E}\left(\mathrm{M}_{2} \mathrm{~S}_{129} \mathrm{~S}_{138} \mathrm{M}_{169} \mathrm{~N}_{176} \mathrm{~S}_{225}\right)$, structured in 14 genotypes [34]. The presence of four instead of five octapeptide repeats is new in Rangifer but was already observed within Capreolinae subfamily in Hydropotes inermis in Chinese water deer [111]. The non-synonymous substitution S138N was not detected, all analysed reindeer being 138SS. Variants A (46.3\%) and B (30.4\%) were the most common. Variants D and $\mathrm{E}$ were not detected among CWD cases. Variant B was more frequent in controls and variants $\mathrm{A}$ and $\mathrm{C}$ were overrepresented among CWD cases, with $\mathrm{A} / \mathrm{A}$ and $\mathrm{A} / \mathrm{C}$ animals presenting a significant CWD risk. These results are concordant with real-time quaking-induced in vitro conversion, where recombinant PrP expressing variants $\mathrm{B}$ and $E$ had significantly lower amplification rate than variant A upon conversion with CWD prion seeds [103].

Experimentally, reindeer can contract CWD after oral inoculation with CWD prions from WTD or Elk or after intracerebral inoculation with the aforementioned or mule deer prions. 138SN reindeer have a prolonged incubation period with the absence of typical clinical CWD symptoms at least until 60 months post-inoculation compared to 138SS reindeer, suggesting a partially protective effect of the S138N substitution [112]. 138SN animals had a significant lower lymphoreticular system involvement compared to $138 \mathrm{SS}$ and $138 \mathrm{NN}$ reindeer [113]. In vitro conversion of cervid $\operatorname{PrP} 138 \mathrm{~N}$ by CWD seeds was shown to be less efficient than that of cervid $\operatorname{Pr} P$ 138S [114]. However, when housed in contact or adjacent to CWD-infected reindeer, $\operatorname{PrP}^{\mathrm{CWD}}$ could be found in the lymphoid tissue and brainstem of $138 \mathrm{NN}$ animals [113].

Overall, PRNP genetic modulations of CWD propagation were identified in reindeer with a protective influence of $138 \mathrm{~N}$ and of variants $\mathrm{B}\left(\mathrm{V}_{2} \mathrm{G}_{129} \mathrm{~S}_{138} \mathrm{~V}_{169} \mathrm{~N}_{176} \mathrm{Y}_{225}\right), \mathrm{D}$ $\left(\mathrm{V}_{2} \mathrm{G}_{129} \mathrm{~S}_{138} \mathrm{~V}_{169} \mathrm{D}_{176} \mathrm{~S}_{225}\right)$ and $\mathrm{E}\left(\mathrm{M}_{2} \mathrm{~S}_{129} \mathrm{~S}_{138} \mathrm{M}_{169} \mathrm{~N}_{176} \mathrm{~S}_{225}\right)$, $[34,103,112-114]$. It is possible that the protective effect of these variants will be re-evaluated after characterization of the culled population from Nordfjella $(N=2024)$.

\subsubsection{Capreolus capreolus or roe deer}

To date, no polymorphism was found in Roe deer from Great Britain $(N=297)$, Alpine arc of Italy $(N=189)$, Northeast of Spain $(N=44)$ or Sweden $(N=11)$. Only one synonymous substitution at codon 24 was detected in two Swedish animals. This lack of diversity may be due to the relative small number of animals analysed and/or population bottleneck $[110,111,115,116]$.

\subsubsection{Alces alces or moose}

To date, nucleotide variants have been identified in moose at 12 positions; 8 synonymous substitutions at aa positions $63,65,77,108,120,128,225$ and 243 and 4 non-synonymous substitutions at aa positions $\mathrm{T} 36 \mathrm{~N}$, S100R, K109Q and M209I [39, 110, 117-119].

In wild moose, natural CWD infections are rare and one explanation is their tendency to be more solitary than other dense social aggregated Cervidae. In Colorado, one affected 209MM moose shot in 2005 and two others shot in 2006 were reported [118]. In Europe, several moose CWD cases were reported, 7 in Norway (including 3 homozygotes moose $\mathrm{K}_{109} \mathrm{M}_{209}$ ), 4 in Sweden and 2 in Finland [37, 38, 40, 41].

Following experimental oral inoculation with CWD prions from mule deer, three captive Shira's moose died without showing any clinical signs indicative of a prion disease. Immunohistochemical evidence for $\mathrm{PrP} \mathrm{PWD}^{\mathrm{CWD}}$ 
accumulation was observed in a 209MM female that died 465 days post-inoculation and one male that died 113 days post-inoculation. The $\operatorname{PrP}$ sequence of the male was not determined because of the lack of suitable tissue for DNA extraction [117]. The third moose that died 567 days after inoculation was negative for $\operatorname{PrP}^{\mathrm{CWD}}$ and was 209 MI heterozygous.

It remains difficult to have a precise estimation of the PRNP polymorphisms in moose because of the limited amount of available data. To our knowledge, only data from 163 moose from Alberta, 44 from Alaska, 17 from British Columbia, 15 from Sweden and 7 from Alaska have been published [82, 110, 119].

\subsection{Subfamily Cervinae}

\subsubsection{Cervus elaphus canadensis (wapiti) and Cervus elaphus nelsoni (rocky mountain elk)}

To date, nucleotides variants were observed in Elk at 3 positions; 2 synonymous substitutions at aa positions 21 and 104 and 1 non-synonymous substitution at aa position 132, M132L, corresponding to the polymorphic position 129 in humans [120-122].

Codon 226 in elk plays a critical role in CWD prion strain selection and $\mathrm{PrP}^{\mathrm{C}}$ to $\mathrm{PrP}^{\mathrm{Sc}}$ conversion. Indeed, aa differences at this position controlled (sub)strain selection from different CWD isolates in experimentally inoculated transgenic mouse models [123, 124]. Using a gene-targeted strategy to express physiological levels of $\mathrm{PrP}^{\mathrm{C}}$ expressing either $\mathrm{Q}$ or $\mathrm{E}$ at codon 226 , which is the only aa difference between mule deer and elk, Bian et al. [123] showed that this polymorphism favoured the selection of either CWD1 (E226) or CWD2 (Q226) conformers in transgenic mice. High resolution nuclear magnetic resonance structure analysis of elk PrP showed that this aa difference could influence the long-range intramolecular interactions and packing of the $\beta 2-\alpha 2$ loop and the $C$ terminus of the $\alpha 3$ helix of Cervidae [47, 125, 126].

After experimental oral inoculation, a 132 PRNP genotype-related infection pattern was identified in elk. 132 MM elk developed disease 23 months post-inoculation, ML in 40 months and LL in 59 to 63 months [127, 128]. After intracranial inoculation of groups of $\operatorname{Tg} 12$ mice that express M132 elk prion protein, it was suggested that the CWD prion isolated from LL132 elk is a novel CWD strain [129].

A study on 565 elk performed between 2016 and 2018, from a private depopulated land (overall 33\% CWD prevalence) from Colorado where CWD was first reported in 2004, showed that $132 \mathrm{MM}$ elk were nearly 2 and 3.5 times more likely to be identified as CWD-positive compared to $132 \mathrm{ML}$ and $132 \mathrm{LL}$ elk, respectively. In addition, 132MM elk were found to be CWD-positive a year sooner, on average, compared to their $132 \mathrm{ML}$ counterparts [130].
Interestingly, a recent study described natural adaptation of Elk population to CWD by favouring the $132 \mathrm{~L}$ allele [131]. A positive correlation between CWD prevalence and the frequency of the 132L allele was found in 1018 elk collected from multiple populations, 3 nonexposed populations $(N=533)$ and 2 populations where CWD was detected 35 years ago $(N=485)$. No additional variants influencing CWD status were observed in a study analysing the promotor region, exons, splice sites, 3'untranslated region, and flanking regions of the PRNP gene from 559 captive and free-ranging elk in Colorado, Montana, Minnesota, Nebraska, Oklahoma and South Dakota [122].

\subsubsection{Cervus elaphus elaphus or European red deer}

To date, nucleotide variants were identified in red deer at 12 positions; 6 synonymous substitutions at aa positions $15,21,63,78,79,136$, and 6 non-synonymous substitutions at aa positions G59S, T98A, P168S, M208I, Q226E and $1247 \mathrm{~L}$.

In Europe, PRNP genetic variations are available from 1124 European red deer from 7 Great Britain regions $(N=627), 3$ Northeast regions of Spain $(N=209)$, Italy $(N=191), 6$ counties in Norway $(N=50+1 C W D+)$ and from Western and Eastern lineage from the Czech Republic $(N=46)[42,111,115,116,132]$. Three nonsynonymous substitutions, G59S, M208I and I247L, and 1 synonymous (position 63) were observed only on single individuals. Four PrP variants were present $\left(\mathrm{T}_{98} \mathrm{P}_{168} \mathrm{E}_{226}\right.$, $\mathrm{T}_{98} \mathrm{P}_{168} \mathrm{Q}_{226}, \mathrm{~A}_{98} \mathrm{P}_{168} \mathrm{Q}_{226}, \mathrm{~A}_{98} \mathrm{~S}_{168} \mathrm{Q}_{226}$ ) with regional variations between Scotland and/or Northern and/or Southern England.

To our knowledge, only three naturally occurring CWD cases have been reported. One positive case, a near term pregnant female, was found among a captive herd of 500 heads in Minnesota [133]. Another case was reported in a farm in Quebec (Canadian Food Inspection Agency, 2018). One 226 EE was shot in Norway in October 2017 [42]. Under experimental conditions, four red deer (two 226QE, one 226QQ, one 226EE) developed clinical signs of CWD 18 to 20 months after oral inoculation with infectious CWD material from elk [134].

\subsubsection{Cervus nippon or sika deer}

Two aa variations have been identified in sequenced sika deer PrP, S100G and Q226E [111, 135-137]. If the E226 and Q226 alleles were equally present in the tested population in China and Korea, the G100 allele was only detected in $3 \%$ of the animals, in association with the E226 aa and only the Q226 allele was detected in Europe pure sika. Efficient oral transmission of CWD from Elk to Sika deer was reported [32], but the potential impact of 
the above-mentioned allelic variations was not tested in this species.

\subsubsection{Dama dama dama or fallow deer}

To date, the number of PRNP sequences of fallow deer across studies is rather low. The 115 genotypes available are from Great Britain $(N=66)$, Northeast of Spain $(N=15)$, Sweden $(N=11)$ and from an experimental study conducted in Colorado $(N=23)$. Except one synonymous change at codon 138 reported in experimental animals, they all had a single PRNP genotype [110, 111, $116,138]$. It seems that fallow deer own a species-specific asparagine $(\mathrm{N})$ at codon 138. Additionally, they have, like elk, a glutamate at codon 226 and this substitution is known to influence the overall protein folding and strain propagation [47, 124-126]. To date, only experimental transmission of CWD to this species has been described [58].

\section{Conclusion}

CWD has spread into wild cervid populations and continues to dramatically increase both in prevalence and geographic range. Among TSEs, CWD has the widest potential species range and its management in freeranging populations is highly problematic. The number of CWD cases is probably underestimated in Europe and in North America for less highly economically valued species. To date, there is no epidemiological evidence that CWD is associated with human TSEs and no experimental support for its transmission based on limited experimental data with humanized mice. However, more experiments are needed to provide firm conclusions. Furthermore, the risk of novel, potentially zoonotic TSEs via secondary transmission of CWD to farm-species will need dedicated studies $[35,74]$. Recently, a list of thirteen groups of risk factors has been established based on their biological plausibility to spread CWD [35], including (i) natural or man-mediated animal aggregation; (ii) fallen stock or inappropriate disposal of carcasses and slaughter by-products; (iii) environmental persistence of prions; (iv) natural movement of live wild deer from infected areas or (v) sex-related behaviours. This disease causes considerable ecologic, economic and sociologic impacts. As illustrated here, PRNP sequence availability on large sample size is uneven among Cervidae. Generally, game species like white tailed deer, mule deer and elk are more studied. Anyhow, PRNP polymorphisms should be considered as key factors that influence CWD susceptibility or disease rate of progression. It seems so far that all deer, irrespective of their PRNP genotype, are susceptible to CWD, but natural selection of the less susceptible alleles has been identified. The positive impact of these animals if infected is still a matter of debate since CWD does not compromise reproduction, at least in WTD [28, 139]. CWD positive animals with extended time before they succumb to disease likely represent a source of chronic prion shedding within populations and may contribute to environmental contamination. Many genetic approaches where PRNP sequences, genetic relationship, population structure and bottleneck history are used to understand this wildlife disease, but they need to be included into more complex processes. Interactions between hosts, strains and their environment have to be considered. Various CWD strains have already been identified but remain incompletely characterized. CWD can be transmitted horizontally and potentially vertically. Thus, landscape epidemiological studies, combining the fields of landscape ecology with landscape genetics, could foster our understanding and identify factors influencing wildlife dispersal and CWD disease distribution [22, 140]. In the literature, different analytical and statistical methods are proposed for CWD modelling [141]. Recently, a model was provided, based on optimal managing of wildlife populations by using culling to increase disease detection and minimizing undesirable population declines [142]. With an alternative approach of proactive hunting subjected to surveillance, the authors reach 99\% probability of freedom from CWD infection of Norwegian reindeer within 3 to 5 years. For this surveillance, a clear infection pattern, selective harvesting and a population model are needed. CWD is a new challenge in wildlife epidemiology that requires multidisciplinary approaches between scientists and stakeholders, including health and governmental authorities [37]. The social aspect and the role of indigenous communities with their cultural practices shall not be neglected.

\section{Abbreviations \\ CWD: chronic wasting disease; PRNP: prion protein gene; TSE: transmissible spongiform encephalopathy; TSEs: transmissible spongiform encephalopa- thies; CJD: Creutzfeldt-Jakob disease; PrPC: protease-sensitive Cellular PRion Protein; $\operatorname{PrP}^{\mathrm{Sc}}$ : abnormal protease-resistant isoform of the prion protein; BSE: bovine spongiform encephalopathy; CNS: central nervous system; PrPCWD: cer- vid resistant prion protein; WTD: white-tailed deer; PrP: normal cellular Prion Protein; ORF: open reading frame; aa: amino acid; PDB: protein data bank; Gt: gene targeted.}

\section{Acknowledgements \\ We are very grateful to Dr Human Rezaei (INRAE-VIM) for helpful discussions on observed cervid PrP polymorphisms.}

Authors' contributions

All authors wrote the manuscript and approved the final manuscript.

Funding

This work was supported by an ANR Grant (project Eu-CWD 00005793). 


\section{Declarations}

\section{Competing interests}

The authors declare that they have no competing interests.

\section{Author details}

${ }^{1}$ University Paris-Saclay, INRAE, AgroParisTech, GABI, 78350 Jouy-en-Josas, France. ${ }^{2}$ UMR INRAE ENVT 1225 - IHAP, École Nationale Vétérinaire de Toulouse, 31076 Toulouse, France. ${ }^{3}$ University Paris-Saclay, INRAE, UVSQ, VIM, 78350 Jouy-en-Josas, France.

\section{Received: 28 May 2021 Accepted: 10 August 2021}

Published online: 07 October 2021

\section{References}

1. Williams ES (2005) Chronic wasting disease. Vet Pathol 42:530-549. https://doi.org/10.1354/vp.42-5-530

2. Arifin MI, Hannaoui S, Chang SC, Thapa S, Schatzl HM, Gilch S (2021) Cervid prion protein polymorphisms: role in chronic wasting disease pathogenesis. Int J Mol Sci 22:2271. https://doi.org/10.3390/ijms220522 71

3. Haley NJ, Hoover EA (2015) Chronic wasting disease of cervids: current knowledge and future perspectives. Annu Rev Anim Biosci 3:305-325. https://doi.org/10.1146/annurev-animal-022114-111001

4. Mathiason CK, Hays SA, Powers J, Hayes-Klug J, Langenberg J, Dahmes SJ, Osborn DA, Miller KV, Warren RJ, Mason GL, Hoover EA (2009) Infectious prions in pre-clinical deer and transmission of chronic wasting disease solely by environmental exposure. PLoS One 4:e5916. https:// doi.org/10.1371/journal.pone.0005916

5. Denkers ND, Hoover CE, Davenport KA, Henderson DM, McNulty EE, Nalls AV, Mathiason CK, Hoover EA (2020) Very low oral exposure to prions of brain or saliva origin can transmit chronic wasting disease. PLoS One 15:e0237410. https://doi.org/10.1371/journal.pone.0237410

6. EFSA Panel on Biological Hazards (BIOHAZ), Ricci A, Allende A, Bolton $D$, Chemaly M, Davies R, Fernández Escámez PS, Gironés R, Herman L, Koutsoumanis K, Lindqvist R, Nørrung B, Robertson L, Sanaa M, Skandamis P, Snary E, Speybroeck N, Ter Kuile B, Threlfall J, Wahlström H, Benestad S, Gavier-Widen D, Miller MW, Ru G, Telling GC, Tryland M, Ortiz Pelaez A, Simmons M (2017) Chronic wasting disease (CWD) in cervids. EFSA J 15:e04667. https://doi.org/10.2903/j.efsa.2017.4667

7. Mathiason CK, Powers JG, Dahmes SJ, Osborn DA, Miller KV, Warren RJ, Mason GL, Hays SA, Hayes-Klug J, Seelig DM, Wild MA, Wolfe LL, Spraker TR, Miller MW, Sigurdson CJ, Telling GC, Hoover EA (2006) Infectious prions in the saliva and blood of deer with chronic wasting disease. Science 314:133-136. https://doi.org/10.1126/science.1132661

8. Mammadova N, Cassmann E, Greenlee JJ (2020) Successful transmission of the chronic wasting disease (CWD) agent to white-tailed deer by intravenous blood transfusion. Res Vet Sci 133:304-306. https://doi. org/10.1016/j.rvsc.2020.10.009

9. Fox KA, Jewell JE, Williams ES, Miller MW (2006) Patterns of PrPCWD accumulation during the course of chronic wasting disease infection in orally inoculated mule deer (Odocoileus hemionus). J Gen Virol 87:3451-3461. https://doi.org/10.1099/vir.0.81999-0

10. Sigurdson CJ, Spraker TR, Miller MW, Oesch B, Hoover EA (2001) PrPCWD in the myenteric plexus, vagosympathetic trunk and endocrine glands of deer with chronic wasting disease. J Gen Virol 82:2327-2334. https:// doi.org/10.1099/0022-1317-82-10-2327

11. Race B, Meade-White KD, Miller MW, Barbian KD, Rubenstein R, LaFauci G, Cervenakova L, Favara C, Gardner D, Long D, Parnell M, Striebel J, Priola SA, Ward A, Williams ES, Race R, Chesebro B (2009) Susceptibilities of nonhuman primates to chronic wasting disease. Emerg Infect Dis 15:1366-1376. https://doi.org/10.3201/eid1509.090253

12. Mysterud A, Ytrehus B, Tranulis MA, Rauset GR, Rolandsen CM, Strand O (2020) Antler cannibalism in reindeer. Sci Rep 10:22168. https://doi.org/ 10.1038/s41598-020-79050-2

13. Georgsson G, Sigurdarson S, Brown P (2006) Infectious agent of sheep scrapie may persist in the environment for at least 16 years. J Gen Virol 87:3737-3740. https://doi.org/10.1099/vir.0.82011-0
14. Johnson CJ, Pedersen JA, Chappell RJ, McKenzie D, Aiken JM (2007) Oral transmissibility of prion disease is enhanced by binding to soil particles. PLoS Pathog 3:e93. https://doi.org/10.1371/journal.ppat.0030093

15. David Walter W, Walsh DP, Farnsworth ML, Winkelman DL, Miller MW (2011) Soil clay content underlies prion infection odds. Nat Commun 2:200. https://doi.org/10.1038/ncomms1203

16. Dorak SJ, Green ML, Wander MM, Ruiz MO, Buhnerkempe MG, Tian T, Novakofski JE, Mateus-Pinilla NE (2017) Clay content and pH: soil characteristic associations with the persistent presence of chronic wasting disease in northern Illinois. Sci Rep 7:18062. https://doi.org/10.1038/ s41598-017-18321-x

17. Kuznetsova A, Cullingham C, McKenzie D, Aiken JM (2018) Soil humic acids degrade CWD prions and reduce infectivity. PLoS Pathog 14:e1007414. https://doi.org/10.1371/journal.ppat.1007414

18. Kuznetsova A, McKenzie D, Cullingham C, Aiken JM (2020) Long-term incubation PrPCWD with soils affects prion recovery but not infectivity. Pathog Basel Switz 9:E311. https://doi.org/10.3390/pathogens9040311

19. Nichols TA, Pulford B, Wyckoff AC, Meyerett C, Michel B, Gertig K, Hoover EA, Jewell JE, Telling GC, Zabel MD (2009) Detection of proteaseresistant cervid prion protein in water from a CWD-endemic area. Prion 3:171-183. https://doi.org/10.4161/pri.3.3.9819

20. Plummer IH, Johnson CJ, Chesney AR, Pedersen JA, Samuel MD (2018) Mineral licks as environmental reservoirs of chronic wasting disease prions. PLoS One 13:e0196745. https://doi.org/10.1371/journal.pone. 0196745

21. Janousek WM, Graves TA, Berman EE, Chong GW, Cole EK, Dewey SR, Johnston AN, Cross PC (2021) Human activities and weather drive contact rates of wintering elk. J Appl Ecol 58:667-676. https://doi.org/ $10.1111 / 1365-2664.13818$

22. Escobar LE, Pritzkow S, Winter SN, Grear DA, Kirchgessner MS, Dominguez-Villegas E, Machado G, Townsend Peterson A, Soto C (2020) The ecology of chronic wasting disease in wildlife. Biol Rev Camb Philos Soc 95:393-408. https://doi.org/10.1111/brv.12568

23. Williams ES, Young S (1980) Chronic wasting disease of captive mule deer: a spongiform encephalopathy. J Wildl Dis 16:89-98. https://doi. org/10.7589/0090-3558-16.1.89

24. Spraker TR, Miller MW, Williams ES, Getzy DM, Adrian WJ, Schoonveld GG, Spowart RA, O'Rourke KI, Miller JM, Merz PA (1997) Spongiform encephalopathy in free-ranging mule deer (Odocoileus hemionus), white-tailed deer (Odocoileus virginianus) and Rocky Mountain elk (Cervus elaphus nelsoni) in northcentral Colorado. J Wildl Dis 33:1-6. https:// doi.org/10.7589/0090-3558-33.1.1

25. Dubé C, Mehren KG, Barker IK, Peart BL, Balachandran A (2006) Retrospective investigation of chronic wasting disease of cervids at the Toronto Zoo, 1973-2003. Can Vet J 47:1185-1193

26. Kahn S, Dubé C, Bates L, Balachandran A (2004) Chronic wasting disease in Canada: Part 1. Can Vet J 45:397-404

27. Keane DP, Barr DJ, Bochsler PN, Hall SM, Gidlewski T, O'Rourke KI, Spraker TR, Samuel MD (2008) Chronic wasting disease in a Wisconsin white-tailed deer farm. J Vet Diagn Invest 20:698-703. https://doi.org/ 10.1177/104063870802000534

28. Edmunds DR, Kauffman MJ, Schumaker BA, Lindzey FG, Cook WE, Kreeger TJ, Grogan RG, Cornish TE (2016) Chronic wasting disease drives population decline of white-tailed deer. PLoS One 11:e0161127. https:// doi.org/10.1371/journal.pone.0161127

29. DeVivo MT, Edmunds DR, Kauffman MJ, Schumaker BA, Binfet J, Kreeger TJ, Richards BJ, Schätzl HM, Cornish TE (2017) Endemic chronic wasting disease causes mule deer population decline in Wyoming. PLoS One 12:e0186512. https://doi.org/10.1371/journal.pone.0186512

30. Lee Y-H, Sohn H-J, Kim M-J, Kim H-J, Lee W-Y, Yun E-I, Tark D-S, Cho I-S, Balachandran A (2013) Strain characterization of the Korean CWD cases in 2001 and 2004. J Vet Med Sci 75:95-98. https://doi.org/10.1292/jvms. 12-0077

31. Kim T-Y, Shon H-J, Joo Y-S, Mun U-K, Kang K-S, Lee Y-S (2005) Additional cases of Chronic Wasting Disease in imported deer in Korea. J Vet Med Sci 67:753-759. https://doi.org/10.1292/jvms.67.753

32. Sohn H-J, Mitchell G, Lee YH, Kim HJ, Park K-J, Staskevicus A, Walther I, Soutyrine A, Balachandran A (2020) Experimental oral transmission of chronic wasting disease to sika deer (Cervus nippon). Prion 14:271-277. https://doi.org/10.1080/19336896.2020.1857038 
33. Benestad SL, Mitchell G, Simmons M, Ytrehus B, Vikøren T (2016) First case of chronic wasting disease in Europe in a Norwegian free-ranging reindeer. Vet Res 47:88. https://doi.org/10.1186/s13567-016-0375-4

34. Güere ME, Våge J, Tharaldsen H, Benestad SL, Vikøren T, Madslien K, Hopp P, Rolandsen CM, Røed KH, Tranulis MA (2020) Chronic wasting disease associated with prion protein gene (PRNP) variation in Norwegian wild reindeer (Rangifer tarandus). Prion 14:1-10. https://doi.org/10. 1080/19336896.2019.1702446

35. EFSA Panel on Biological Hazards (BIOHAZ), Koutsoumanis K, Allende A, Alvarez-Ordoňez A, Bolton D, Bover-Cid S, Chemaly M, Davies R, De Cesare A, Herman L, Hilbert F, Lindqvist R, Nauta M, Peixe L, Ru G, Skandamis P, Suffredini E, Andreoletti O, Benestad SL, Comoy E, Nonno R, da Silva FT, Ortiz-Pelaez A, Simmons MM (2019) Update on chronic wasting disease (CWD) III. EFSA J 17:e05863. https://doi.org/10.2903/j. efsa.2019.5863

36. Viljugrein H, Hopp P, Benestad SL, Nilsen EB, Våge J, Tavornpanich S, Rolandsen CM, Strand O, Mysterud A (2019) A method that accounts for differential detectability in mixed samples of long-term infections with applications to the case of chronic wasting disease in cervids. Methods Ecol Evol 10:134-145. https://doi.org/10.1111/2041-210X.13088

37. Maraud S, Roturier S (2021) Chronic wasting disease (CWD) in Sami reindeer herding: the socio-political dimension of an epizootic in an indigenous context. Animals 25:297. https://doi.org/10.3390/ani11 020297

38. Våge J, Hopp P, Vikoren, T, Madslien K, Tarpai A, Moldal T, Lafond Benestad S (2020) The surveillance programme for Chronic Wasting Disease (CWD) in free ranging and captive cervids in Norway 2019. Annual Report. Norwegian Veterinary Institute

39. Pirisinu L, Tran L, Chiappini B, Vanni I, Di Bari MA, Vaccari G, Vikøren T, Madslien KI, Våge J, Spraker T, Mitchell G, Balachandran A, Baron T, Casalone C, Rolandsen CM, Røed KH, Agrimi U, Nonno R, Benestad SL (2018) Novel type of chronic wasting disease detected in moose (Alces alces), Norway. Emerg Infect Dis 24:2210-2218. https://doi.org/10.3201/ eid2412.180702

40. Våge J, Hopp, P, Vikøren, T, Madslien, K, Tarpai A, Moldal T, Lafond Benestad S (2019) The surveillance programme for Chronic Wasting Disease (CWD) in free ranging and captive cervids in Norway 2018. Annual Report. Norwegian Veterinary Institute

41. Ågren EO, Sörén K, Gavier-Widén D, Benestad SL, Tran L, Wall K, Averhed G, Doose N, Våge J, Nöremark M (2021) First detection of chronic wasting disease in moose (Alces alces) in Sweden. J Wildl Dis 57:461-463. https://doi.org/10.7589/JWD-D-20-00141

42. Vikøren T, Våge J, Madslien Kl, Røed KH, Rolandsen CM, Tran L, Hopp P, Veiberg V, Heum M, Moldal T, das Neves CG, Handeland K, Ytrehus B, Kolbjørnsen $\varnothing$, Wisløff H, Terland R, Saure B, Dessen KM, Svendsen SG, Nordvik BS, Benestad SL (2019) First detection of chronic wasting disease in a wild red deer (Cervus elaphus) in Europe. J Wild Dis 55:970-972

43. Mysterud A, Benestad SL, Rolandsen CM, Våge J (2021) Policy implications of an expanded chronic wasting disease universe. J Appl Ecol 58:281-285. https://doi.org/10.1111/1365-2664.13783

44. Diaz-Espinoza R, Soto C (2012) High-resolution structure of infectious prion protein: the final frontier. Nat Struct Mol Biol 19:370-377. https:// doi.org/10.1038/nsmb.2266

45. Béringue V, Vilotte $J$-L, Laude $H$ (2008) Prion agent diversity and species barrier. Vet Res 39:47. https://doi.org/10.1051/vetres:2008024

46. Browning SR, Mason GL, Seward T, Green M, Eliason GAJ, Mathiason C, Miller MW, Williams ES, Hoover E, Telling GC (2004) Transmission of prions from mule deer and elk with chronic wasting disease to transgenic mice expressing cervid PrP. J Virol 78:13345-13350. https://doi.org/10. 1128/JVI.78.23.13345-13350.2004

47. Angers R, Christiansen J, Nalls AV, Kang H-E, Hunter N, Hoover E, Mathiason CK, Sheetz M, Telling GC (2014) Structural effects of PrP polymorphisms on intra- and interspecies prion transmission. Proc Natl Acad Sci U S A 111:11169-11174. https://doi.org/10.1073/pnas.1404739111

48. Cassard H, Huor A, Espinosa J-C, Douet J-Y, Lugan S, Aron N, Vilette D, Delisle M-B, Marín-Moreno A, Peran P, Beringue V, Torres JM, Ironside JW, Andreoletti O (2020) Prions from sporadic Creutzfeldt-Jakob disease patients propagate as strain mixtures. MBio 11:e00393-20. https://doi. org/10.1128/mBio.00393-20
49. Le Dur A, Laï TL, Stinnakre M-G, Laisné A, Chenais N, Rakotobe S, Passet B, Reine F, Soulier S, Herzog L, Tilly G, Rézaei H, Béringue V, Vilotte J-L, Laude H (2017) Divergent prion strain evolution driven by PrPC expression level in transgenic mice. Nat Commun 8:14170. https://doi.org/10. 1038/ncomms 14170

50. Nonno R, Bari MAD, Cardone F, Vaccari G, Fazzi P, Dell'Omo G, Cartoni C, Ingrosso L, Boyle A, Galeno R, Sbriccoli M, Lipp H-P, Bruce M, Pocchiari M, Agrimi U (2006) Efficient transmission and characterization of Creutzfeldt-Jakob disease strains in bank voles. PLoS Pathog 2:e12. https://doi.org/10.1371/journal.ppat.0020012

51. Collinge J, Clarke AR (2007) A general model of prion strains and their pathogenicity. Science 318:930-936. https://doi.org/10.1126/science. 1138718

52. Di Bari MA, Nonno R, Castilla J, D’Agostino C, Pirisinu L, Riccardi G, Conte M, Richt J, Kunkle R, Langeveld J, Vaccari G, Agrimi U (2013) Chronic wasting disease in bank voles: characterisation of the shortest incubation time model for prion diseases. PLoS Pathog 9:e1003219. https:// doi.org/10.1371/journal.ppat.1003219

53. Nonno R, Di Bari MA, Pirisinu L, D’Agostino C, Vanni I, Chiappini B, Marcon S, Riccardi G, Tran L, Vikøren T, Våge J, Madslien K, Mitchell G, Telling GC, Benestad SL, Agrimi U (2020) Studies in bank voles reveal strain differences between chronic wasting disease prions from Norway and North America. Proc Natl Acad Sci U S A 117:31417-31426. https://doi. org/10.1073/pnas.2013237117

54. Duque Velásquez C, Kim C, Haldiman T, Kim C, Herbst A, Aiken J, Safar JG, McKenzie D (2020) Chronic wasting disease (CWD) prion strains evolve via adaptive diversification of conformers in hosts expressing prion protein polymorphisms. J Biol Chem 295:4985-5001. https://doi. org/10.1074/jbc.RA120.012546

55. Hannaoui S, Amidian S, Cheng YC, Duque Velásquez C, Dorosh L, Law S, Telling G, Stepanova M, McKenzie D, Wille H, Gilch S (2017) Destabilizing polymorphism in cervid prion protein hydrophobic core determines prion conformation and conversion efficiency. PLoS Pathog 13:e1006553. https://doi.org/10.1371/journal.ppat.1006553

56. Gilbert C, Ropiquet A, Hassanin A (2006) Mitochondrial and nuclear phylogenies of Cervidae (Mammalia, Ruminantia): systematics, morphology, and biogeography. Mol Phylogenet Evol 40:101-117. https:// doi.org/10.1016/j.ympev.2006.02.017

57. Nalls AV, McNulty E, Powers J, Seelig DM, Hoover C, Haley NJ, HayesKlug J, Anderson K, Stewart P, Goldmann W, Hoover EA, Mathiason CK (2013) Mother to offspring transmission of chronic wasting disease in reeves' muntjac deer. PLoS One 8:e71844. https://doi.org/10.1371/journ al.pone.0071844

58. Hamir AN, Greenlee JJ, Nicholson EM, Kunkle RA, Richt JA, Miller JM, Hall M (2011) Experimental transmission of chronic wasting disease (CWD) from elk and white-tailed deer to fallow deer by intracerebral route: final report. Can J Vet Res 75:152-156

59. Moore SJ, West Greenlee MH, Kondru N, Manne S, Smith JD, Kunkle RA, Kanthasamy A, Greenlee JJ (2017) Experimental transmission of the chronic wasting disease agent to swine after oral or intracranial inoculation. J Virol 91:e00926-17. https://doi.org/10.1128/JVI.00926-17

60. Hamir AN, Kunkle RA, Richt JA, Miller JM, Cutlip RC, Jenny AL (2005) Experimental transmission of sheep scrapie by intracerebral and oral routes to genetically susceptible Suffolk sheep in the United States. J Vet Diagn Invest 17:3-9. https://doi.org/10.1177/104063870501700103

61. Hamir AN, Kunkle RA, Cutlip RC, Miller JM, Williams ES, Richt JA (2006) Transmission of chronic wasting disease of mule deer to Suffolk sheep following intracerebral inoculation. J Vet Diagn Invest 18:558-565. https://doi.org/10.1177/104063870601800606

62. Hamir AN, Kunkle RA, Cutlip RC, Miller JM, O'Rourke KI, Williams ES, Miller MW, Stack MJ, Chaplin MJ, Richt JA (2005) Experimental transmission of chronic wasting disease agent from mule deer to cattle by the intracerebral route. J Vet Diagn Invest 17:276-281. https://doi.org/10. 1177/104063870501700313

63. Hamir AN, Kunkle RA, Miller JM, Greenlee JJ, Richt JA (2006) Experimental second passage of chronic wasting disease (CWD mule deer) agent to cattle. J Comp Pathol 134:63-69. https://doi.org/10.1016/j.jcpa.2005.07. 001

64. Hamir AN, Miller JM, Kunkle RA, Hall SM, Richt JA (2007) Susceptibility of cattle to first-passage intracerebral inoculation with chronic wasting 
disease agent from white-tailed deer. Vet Pathol 44:487-493. https:// doi.org/10.1354/vp.44-4-487

65. Hamir AN, Kehrli ME, Kunkle RA, Greenlee JJ, Nicholson EM, Richt JA, Miller JM, Cutlip RC (2011) Experimental interspecies transmission studies of the transmissible spongiform encephalopathies to cattle: comparison to bovine spongiform encephalopathy in cattle. J Vet Diagn Invest 23:407-420. https://doi.org/10.1177/1040638711403404

66. Greenlee JJ, Nicholson EM, Smith JD, Kunkle RA, Hamir AN (2012) Susceptibility of cattle to the agent of chronic wasting disease from elk after intracranial inoculation. J Vet Diagn Invest 24:1087-1093. https:// doi.org/10.1177/1040638712461249

67. Béringue V, Herzog L, Jaumain E, Reine F, Sibille P, Dur AL, Vilotte J-L, Laude H (2012) Facilitated cross-species transmission of prions in extraneural tissue. Science 335:472-475. https://doi.org/10.1126/scien ce.1215659

68. Espinosa JC, Marín-Moreno A, Aguilar-Calvo P, Torres JM (2021) Met166Glu168 residues in human PrP $\beta 2$-a2 loop account for evolutionary resistance to prion infection. Neuropathol Appl Neurobiol 47:506-518. https://doi.org/10.1111/nan.12676

69. Heisey DM, Mickelsen NA, Schneider JR, Johnson CJ, Johnson CJ, Langenberg JA, Bochsler PN, Keane DP, Barr DJ (2010) Chronic wasting disease (CWD) susceptibility of several North American rodents that are sympatric with cervid CWD epidemics. J Virol 84:210-215. https://doi. org/10.1128/JVI.00560-09

70. Raymond GJ, Raymond LD, Meade-White KD, Hughson AG, Favara C, Gardner D, Williams ES, Miller MW, Race RE, Caughey B (2007) Transmission and adaptation of chronic wasting disease to hamsters and transgenic mice: evidence for strains. J Virol 81:4305-4314. https://doi. org/10.1128/JVI.02474-06

71. Perrott MR, Sigurdson CJ, Mason GL, Hoover EA (2012) Evidence for distinct chronic wasting disease (CWD) strains in experimental CWD in ferrets. J Gen Virol 93:212-221. https://doi.org/10.1099/vir.0.035006-0

72. Hamir AN, Miller JM, Cutlip RC, Stack MJ, Chaplin MJ, Jenny AL, Williams ES (2003) Experimental inoculation of scrapie and chronic wasting disease agents in raccoons (Procyon lotor). Vet Rec 153:121-123. https:// doi.org/10.1136/vr.153.4.121

73. Mathiason CK, Nalls AV, Seelig DM, Kraft SL, Carnes K, Anderson KR, Hayes-Klug J, Hoover EA (2013) Susceptibility of domestic cats to chronic wasting disease. JVirol 87:1947-1956. https://doi.org/10.1128/ JVI.02592-12

74. Houston F, Andréoletti O (2019) Animal prion diseases: the risks to human health. Brain Pathol Zurich Switz 29:248-262. https://doi.org/10. 1111/bpa.12696

75. Race B, Meade-White KD, Phillips K, Striebel J, Race R, Chesebro B (2014) Chronic wasting disease agents in nonhuman primates. Emerg Infect Dis 20:833-837. https://doi.org/10.3201/eid2005.130778

76. Race B, Williams K, Orrú CD, Hughson AG, Lubke L, Chesebro B (2018) Lack of transmission of chronic wasting disease to cynomolgus macaques. JVirol 92:e00550-18. https://doi.org/10.1128/JVI.00550-18

77. Osterholm MT, Anderson CJ, Zabel MD, Scheftel JM, Moore KA, Appleby BS (2019) Chronic wasting disease in cervids: implications for prion transmission to humans and other animal species. MBio 10:e0109119. https://doi.org/10.1128/mBio.01091-19

78. Sandberg MK, Al-Doujaily H, Sigurdson CJ, Glatzel M, O'Malley C, Powell C, Asante EA, Linehan JM, Brandner S, Wadsworth JDF, Collinge J (2010) Chronic wasting disease prions are not transmissible to transgenic mice overexpressing human prion protein. J Gen Virol 91:2651-2657. https:// doi.org/10.1099/vir.0.024380-0

79. Kong Q, Huang S, Zou W, Vanegas D, Wang M, Wu D, Yuan J, Zheng M, Bai H, Deng H, Chen K, Jenny AL, O'Rourke K, Belay ED, Schonberger LB, Petersen RB, Sy M-S, Chen SG, Gambetti P (2005) Chronic wasting disease of elk: transmissibility to humans examined by transgenic mouse models. J Neurosci Off J Soc Neurosci 25:7944-7949. https://doi.org/10. 1523/JNEUROSCI.2467-05.2005

80. Wadsworth JDF, Joiner S, Linehan JM, Jack K, Al-Doujaily H, Costa H, Ingold T, Taema M, Zhang F, Sandberg MK, Brandner S, Tran L, Vikøren T, Văge J, Madslien K, Ytrehus B, Benestad SL, Asante EA, Collinge J (2021) Humanised transgenic mice are resistant to chronic wasting disease prions from Norwegian reindeer and moose. J Infect Dis. https://doi. org/10.1093/infdis/jiab033
81. Padilla D, Béringue V, Espinosa JC, Andreoletti O, Jaumain E, Reine F, Herzog L, Gutierrez-Adan A, Pintado B, Laude H, Torres JM (2011) Sheep and goat BSE propagate more efficiently than cattle BSE in human PrP transgenic mice. PLoS Pathog 7:e1001319. https://doi.org/10.1371/ journal.ppat.1001319

82. Cullingham Cl, Peery RM, Dao A, McKenzie DI, Coltman DW (2020) Predicting the spread-risk potential of chronic wasting disease to sympatric ungulate species. Prion 14:56-66. https://doi.org/10.1080/19336 896.2020.1720486

83. Elsen JM, Amigues Y, Schelcher F, Ducrocq V, Andreoletti O, Eychenne F, Khang JV, Poivey JP, Lantier F, Laplanche JL (1999) Genetic susceptibility and transmission factors in scrapie: detailed analysis of an epidemic in a closed flock of Romanov. Arch Virol 144:431-445. https://doi.org/10. 1007/s007050050516

84. Hunter N, Foster JD, Goldmann W, Stear MJ, Hope J, Bostock C (1996) Natural scrapie in a closed flock of Cheviot sheep occurs only in specific PrP genotypes. Arch Virol 141:809-824. https://doi.org/10.1007/BF017 18157

85. Hunter N (1997) PrP genetics in sheep and the applications for scrapie and BSE. Trends Microbiol 5:331-334. https://doi.org/10.1016/s0966842x(97)01081-0

86. Curcio L, Sebastiani C, Di Lorenzo P, Lasagna E, Biagetti M (2016) Review: A review on classical and atypical scrapie in caprine: Prion protein gene polymorphisms and their role in the disease. Anim Int J Anim Biosci 10:1585-1593. https://doi.org/10.1017/S1751731116000653

87. Barillet F, Mariat D, Amigues Y, Faugeras R, Caillat H, Moazami-Goudarzi K, Rupp R, Babilliot JM, Lacroux C, Lugan S, Schelcher F, Chartier C, Corbière F, Andréoletti O, Perrin-Chauvineau C (2009) Identification of seven haplotypes of the caprine PrP gene at codons 127, 142, 154, 211, 222 and 240 in French Alpine and Saanen breeds and their association with classical scrapie. J Gen Virol 90:769-776. https://doi.org/10.1099/ vir.0.006114-0

88. Corbière F, Perrin-Chauvineau $C$, Lacroux $C$, Costes $P$, Thomas M, Brémaud I, Martin S, Lugan S, Chartier C, Schelcher F, Barillet F, Andreoletti $\mathrm{O}$ (2013) PrP-associated resistance to scrapie in five highly infected goat herds. J Gen Virol 94:241-245. https://doi.org/10.1099/vir.0.047225-0

89. Papasavva-Stylianou P, Kleanthous M, Toumazos P, Mavrikiou P (1997) Loucaides P (2007) Novel polymorphisms at codons 146 and 151 in the prion protein gene of Cyprus goats, and their association with natural scrapie. Vet J Lond Engl 173:459-462. https://doi.org/10.1016/j.tvjl.2005. 09.013

90. Haase B, Doherr MG, Seuberlich T, Drögemüller C, Dolf G, Nicken P, Schiebel K, Ziegler U, Groschup MH, Zurbriggen A, Leeb T (2007) PRNP promoter polymorphisms are associated with BSE susceptibility in Swiss and German cattle. BMC Genet 8:15. https://doi.org/10. 1186/1471-2156-8-15

91. Lee HS, Brown P, Cervenáková L, Garruto RM, Alpers MP, Gajdusek DC, Goldfarb LG (2001) Increased susceptibility to Kuru of carriers of the PRNP 129 methionine/methionine genotype. J Infect Dis 183:192196. https://doi.org/10.1086/317935

92. Asante EA, Smidak M, Grimshaw A, Houghton R, Tomlinson A, Jeelani A, Jakubcova T, Hamdan S, Richard-Londt A, Linehan JM, Brandner S, Alpers M, Whitfield J, Mead S, Wadsworth JDF, Collinge J (2015) A naturally occurring variant of the human prion protein completely prevents prion disease. Nature 522:478-481. https://doi.org/10.1038/ nature 14510

93. Haley NJ, Merrett K, Buros Stein A, Simpson D, Carlson A, Mitchell G, Staskevicius A, Nichols T, Lehmkuhl AD, Thomsen BV (2019) Estimating relative CWD susceptibility and disease progression in farmed white-tailed deer with rare PRNP alleles. PLoS One 14:e0224342. https://doi.org/10.1371/journal.pone.0224342

94. Ishida Y, Tian T, Brandt AL, Kelly AC, Shelton P, Roca AL, Novakofski J, Mateus-Pinilla NE (2020) Association of chronic wasting disease susceptibility with prion protein variation in white-tailed deer (Odocoileus virginianus). Prion 14:214-225. https://doi.org/10.1080/19336 896.2020 .1805288

95. Chafin TK, Douglas MR, Martin BT, Zbinden ZD, Middaugh CR, Ballard JR, Gray MC, White D, Douglas ME (2020) Age structuring and spatial heterogeneity in prion protein gene (PRNP) polymorphism in 
white-tailed deer. Prion 14:238-248. https://doi.org/10.1080/19336 896.2020.1832947

96. Miller WL, Walter WD (2019) Spatial heterogeneity of prion gene polymorphisms in an area recently infected by chronic wasting disease. Prion 13:65-76. https://doi.org/10.1080/19336896.2019.15830 42

97. Wilson GA, Nakada SM, Bollinger TK, Pybus MJ, Merrill EH, Coltman DW (2009) Polymorphisms at the PRNP gene influence susceptibility to chronic wasting disease in two species of deer (Odocoileus Spp.) in western Canada. J Toxicol Environ Health A 72:1025-1029. https:// doi.org/10.1080/15287390903084264

98. Otero A, Duque Velásquez C, Johnson C, Herbst A, Bolea R, Badiola JJ, Aiken J, McKenzie D (2019) Prion protein polymorphisms associated with reduced CWD susceptibility limit peripheral PrPCWD deposition in orally infected white-tailed deer. BMC Vet Res 15:50. https://doi. org/10.1186/s12917-019-1794-Z

99. Evans TS, Kirchgessner MS, Eyler B, Ryan CW, Walter WD (2016) Habitat influences distribution of chronic wasting disease in white-tailed deer. J Wildl Manag 80:284-291. https://doi.org/10.1002/jwmg.1004

100. Long ES, Diefenbach DR, Rosenberry CS, Wallingford BD, Grund MD (2005) Forest cover influences dispersal distance of white-tailed deer. J Mammal 86:623-629. https://doi.org/10.1644/1545-1542(2005) 86[623:FCIDDO]2.0.CO;2

101. Johnson CJ, Herbst A, Duque-Velasquez C, Vanderloo JP, Bochsler $P$, Chappell R, McKenzie D (2011) Prion protein polymorphisms affect chronic wasting disease progression. PLoS One 6:e17450. https://doi. org/10.1371/journal.pone.0017450

102. Meade-White K, Race B, Trifilo M, Bossers A, Favara C, Lacasse R, Miller M, Williams E, Oldstone M, Race R, Chesebro B (2007) Resistance to chronic wasting disease in transgenic mice expressing a naturally occurring allelic variant of deer prion protein. J Virol 81:4533-4539. https://doi.org/10.1128/JVI.02762-06

103. Haley NJ, Rielinger R, Davenport KA, O'Rourke K, Mitchell G, Richt JA (2017) Estimating chronic wasting disease susceptibility in cervids using real-time quaking-induced conversion. J Gen Virol 98:28822892. https://doi.org/10.1099/jgv.0.000952

104. Jewell JE, Conner MM, Wolfe LL, Miller MW, Williams ES (2005) Low frequency of PrP genotype 225SF among free-ranging mule deer (Odocoileus hemionus) with chronic wasting disease. J Gen Virol 86:2127-2134. https://doi.org/10.1099/vir.0.81077-0

105. Zink RM, Najar N, Vázquez-Miranda H, Buchanan BL, Loy D, Brodersen BW (2020) Geographic variation in the PRNP gene and its promoter, and their relationship to chronic wasting disease in North American deer. Prion 14:185-192. https://doi.org/10.1080/19336896.2020. 1796250

106. Wolfe LL, Fox KA, Miller MW (2014) "Atypical" chronic wasting disease in PRNP genotype 225FF mule deer. J Wildl Dis 50:660-665. https://doi. org/10.7589/2013-10-274

107. Arifin MI, Staskevicius A, Shim SY, Huang Y-H, Fenton $H$, McLoughlin PD, Mitchell G, Cullingham Cl, Gilch S (2020) Large-scale prion protein genotyping in Canadian caribou populations and potential impact on chronic wasting disease susceptibility. Mol Ecol 29:3830-3840. https:// doi.org/10.1111/mec.15602

108. Cheng YC, Musiani M, Cavedon M, Gilch S (2017) High prevalence of prion protein genotype associated with resistance to chronic wasting disease in one Alberta woodland caribou population. Prion 11:136-142. https://doi.org/10.1080/19336896.2017.1300741

109. Happ GM, Huson HJ, Beckmen KB, Kennedy LJ (2007) Prion protein genes in caribou from Alaska. J Wild Dis 43:224-228. https://doi.org/10. 7589/0090-3558-43.2.224

110. Wik L, Mikko S, Klingeborn M, Stéen M, Simonsson M, Linné T (2012) Polymorphisms and variants in the prion protein sequence of European moose (Alces alces), reindeer (Rangifer tarandus), roe deer (Capreolus capreolus) and fallow deer (Dama dama) in Scandinavia. Prion 6:256-260. https://doi.org/10.4161/pri.19641

111. Robinson AL, Williamson $H$, Güere ME, Tharaldsen H, Baker K, Smith SL, Pérez-Espona S, Krojerová-Prokešová J, Pemberton JM, Goldmann W, Houston F (2019) Variation in the prion protein gene (PRNP) sequence of wild deer in Great Britain and mainland Europe. Vet Res 50:59. https://doi.org/10.1186/s13567-019-0675-6
112. Mitchell GB, Sigurdson CJ, O'Rourke KI, Algire J, Harrington NP, Walther I, Spraker TR, Balachandran A (2012) Experimental oral transmission of chronic wasting disease to reindeer (Rangifer tarandus tarandus). PLoS One 7:e39055. https://doi.org/10.1371/journal.pone.0039055

113. Moore SJ, Kunkle R, Greenlee MHW, Nicholson E, Richt J, Hamir A, Waters WR, Greenlee J (2016) Horizontal transmission of chronic wasting disease in reindeer. Emerg Infect Dis 22:2142-2145. https://doi.org/ 10.3201/eid2212.160635

114. Raymond GJ, Bossers A, Raymond LD, O'Rourke KI, McHolland LE, Bryant PK, Miller MW, Williams ES, Smits M, Caughey B (2000) Evidence of a molecular barrier limiting susceptibility of humans, cattle and sheep to chronic wasting disease. EMBO J 19:4425-4430. https://doi.org/10. 1093/emboj/19.17.4425

115. Peletto S, Perucchini M, Acín C, Dalgleish MP, Reid HW, Rasero R, Sacchi P, Stewart P, Caramelli M, Ferroglio E, Bozzetta E, Meloni D, Orusa R, Robetto S, Gennero S, Goldmann W, Acutis PL (2009) Genetic variability of the prion protein gene (PRNP) in wild ruminants from Italy and Scotland. J Vet Sci 10:115-120. https://doi.org/10.4142/jvs.2009.10.2.115

116. Pitarch JL, Raksa HC, Arnal MC, Revilla M, Martínez D, Fernández de Luco D, Badiola JJ, Goldmann W, Acín C (2018) Low sequence diversity of the prion protein gene (PRNP) in wild deer and goat species from Spain. Vet Res 49:33. https://doi.org/10.1186/s13567-018-0528-8

117. Kreeger TJ, Montgomery DL, Jewell JE, Schultz W, Williams ES (2006) Oral transmission of chronic wasting disease in captive Shira's moose. J Wildl Dis 42:640-645. https://doi.org/10.7589/0090-3558-42.3.640

118. Baeten LA, Powers BE, Jewell JE, Spraker TR, Miller MW (2007) A natural case of chronic wasting disease in a free-ranging moose (Alces alces shirasi). J Wildl Dis 43:309-314. https://doi.org/10.7589/0090-3558-43.2. 309

119. Huson HJ, Happ GM (2006) Polymorphisms of the prion protein gene (PRNP) in Alaskan moose (Alces alces gigas). Anim Genet 37:425-426. https://doi.org/10.1111/j.1365-2052.2006.01466.x

120. Perucchini M, Griffin K, Miller MW, Goldmann W (2008) PrP genotypes of free-ranging wapiti (Cervus elaphus nelsoni) with chronic wasting disease. J Gen Virol 89:1324-1328. https://doi.org/10.1099/vir.0.83424-0

121. O'Rourke KI, Besser TE, Miller MW, Cline TF, Spraker TR, Jenny AL, Wild MA, Zebarth GL, Williams ES (1999) PrP genotypes of captive and free-ranging Rocky Mountain elk (Cervus elaphus nelsoni) with chronic wasting disease. J Gen Virol 80:2765-2679. https://doi.org/10.1099/ 0022-1317-80-10-2765

122. White SN, Spraker TR, Reynolds JO, O'Rourke KI (2010) Association analysis of PRNP gene region with chronic wasting disease in Rocky Mountain elk. BMC Res Notes 3:314. https://doi.org/10.1186/1756-0500-3-314

123. Bian J, Christiansen JR, Moreno JA, Kane SJ, Khaychuk V, Gallegos J, Kim S, Telling GC (2019) Primary structural differences at residue 226 of deer and elk PrP dictate selection of distinct CWD prion strains in genetargeted mice. Proc Natl Acad Sci U S A 116:12478-12487. https://doi. org/10.1073/pnas.1903947116

124. Angers RC, Kang H-E, Napier D, Browning S, Seward T, Mathiason C, Balachandran A, McKenzie D, Castilla J, Soto C, Jewell J, Graham C, Hoover EA, Telling GC (2010) Prion strain mutation determined by prion protein conformational compatibility and primary structure. Science 328:1154-1158. https://doi.org/10.1126/science.1187107

125. Gossert AD, Bonjour S, Lysek DA, Fiorito F, Wüthrich K (2005) Prion protein NMR structures of elk and of mouse/elk hybrids. Proc Natl Acad Sci U S A 102:646-650. https://doi.org/10.1073/pnas.0409008102

126. Slapšak U, Salzano G, Ilc G, Giachin G, Bian J, Telling G, Legname G, Plavec J (2019) Unique structural features of mule deer prion protein provide insights into chronic wasting disease. ACS Omega 4:1991319924. https://doi.org/10.1021/acsomega.9b02824

127. Hamir AN, Gidlewski T, Spraker TR, Miller JM, Creekmore L, Crocheck M, Cline T, O'Rourke KI (2006) Preliminary observations of genetic susceptibility of elk (Cervus elaphus nelsoni) to chronic wasting disease by experimental oral inoculation. J Vet Diagn Invest 18:110-114. https:// doi.org/10.1177/104063870601800118

128. O'Rourke KI, Spraker TR, Zhuang D, Greenlee JJ, Gidlewski TE, Hamir AN (2007) Elk with a long incubation prion disease phenotype have a unique PrPd profile. NeuroReport 18:1935-1938. https://doi.org/10. 1097/WNR.0b013e3282f1ca2f 
129. Moore J, Tatum T, Hwang S, Vrentas C, West Greenlee MH, Kong Q Nicholson E, Greenlee J (2020) Novel strain of the chronic wasting disease agent isolated from experimentally inoculated elk with LL132 prion protein. Sci Rep 10:3148. https://doi.org/10.1038/ s41598-020-59819-1

130. Haley NJ, Henderson DM, Donner R, Wyckoff S, Merrett K, Tennant J, Hoover EA, Love D, Kline E, Lehmkuhl AD, Thomsen BV (2020) Management of chronic wasting disease in ranched elk: conclusions from a longitudinal three-year study. Prion 14:76-87. https://doi.org/10.1080/ 19336896.2020.1724754

131. Monello RJ, Galloway NL, Powers JG, Madsen-Bouterse SA, Edwards WH, Wood ME, O'Rourke KI, Wild MA (2017) Pathogen-mediated selection in free-ranging elk populations infected by chronic wasting disease. Proc Natl Acad Sci U S A 114:12208-12212. https://doi.org/10.1073/pnas. 1707807114

132. Kaluz S, Kaluzova M, Flint AP (1997) Sequencing analysis of prion genes from red deer and camel. Gene 199:283-286. https://doi.org/10.1016/ s0378-1119(97)00382-x

133. Schwabenlander MD, Culhane MR, Hall SM, Goyal SM, Anderson PL, Carstensen M, Wells SJ, Slade WB, Armién AG (2013) A case of chronic wasting disease in a captive red deer (Cervus elaphus). J Vet Diagn Invest 25:573-576. https://doi.org/10.1177/1040638713499914

134. Balachandran A, Harrington NP, Algire J, Soutyrine A, Spraker TR, Jeffrey M, González L, O'Rourke KI (2010) Experimental oral transmission of chronic wasting disease to red deer (Cervus elaphus elaphus): early detection and late stage distribution of protease-resistant prion protein. Can Vet J 51:169-178

135. Meng LP, Zhao DM, Liu HX, Yang JM, Ning ZY, Wu CD, Han CX (2005) Polymorphisms of the prion protein gene (PRNP) in Chinese domestic sika deer (Cervus nippon hortulorum). Anim Genet 36:266-267. https:// doi.org/10.1111/j.1365-2052.2005.01276.x

136. Jeong HJ, Lee JB, Park SY, Song CS, Kim BS, Rho JR, Yoo MH, Jeong BH, Kim YS, Choi IS (2007) Identification of single-nucleotide polymorphisms of the prion protein gene in sika deer (Cervus nippon laiouanus). J Vet Sci 8:299-301. https://doi.org/10.4142/jvs.2007.8.3.299

137. Kataoka N, Nishimura M, Horiuchi M, Ishiguro N (2005) Surveillance of chronic wasting disease in sika deer, Cervus nippon, from Tokachi district in Hokkaido. J Vet Med Sci 67:349-351. https://doi.org/10.1292/jvms.67. 349

138. Rhyan JC, Miller MW, Spraker TR, McCollum M, Nol P, Wolfe LL, Davis TR, Creekmore L, O'Rourke KI (2011) Failure of fallow deer (Dama dama) to develop chronic wasting disease when exposed to a contaminated environment and infected mule deer (Odocoileus hemionus). J Wildl Dis 47:739-744. https://doi.org/10.7589/0090-3558-47.3.739

139. Blanchong JA, Grear DA, Weckworth BV, Keane DP, Scribner KT, Samuel MD (2012) Effects of chronic wasting disease on reproduction and fawn harvest vulnerability in Wisconsin white-tailed deer. J Wildl Dis 48:361-370. https://doi.org/10.7589/0090-3558-48.2.361

140. Blanchong JA, Robinson SJ, Samuel MD, Foster JT (2016) Application of genetics and genomics to wildlife epidemiology: genetics and wildlife epidemiology. J Wildl Manag 80:593-660. https://doi.org/10.1002/ jwmg.1064

141. Winter SN, Escobar LE (2020) Chronic wasting disease modeling: an overview. JWildl Dis 56:741-758. https://doi.org/10.7589/2019-08-213

142. Mysterud A, Hopp P, Alvseike KR, Benestad SL, Nilsen EB, Rolandsen CM, Strand O, Våge J, Viljugrein H (2020) Hunting strategies to increase detection of chronic wasting disease in cervids. Nat Commun 11:4392. https://doi.org/10.1038/s41467-020-18229-7

\section{Publisher's Note}

Springer Nature remains neutral with regard to jurisdictional claims in published maps and institutional affiliations.
Ready to submit your research? Choose BMC and benefit from:

- fast, convenient online submission

- thorough peer review by experienced researchers in your field

- rapid publication on acceptance

- support for research data, including large and complex data types

- gold Open Access which fosters wider collaboration and increased citations

- maximum visibility for your research: over $100 \mathrm{M}$ website views per year

At BMC, research is always in progress.

Learn more biomedcentral.com/submissions 